\title{
A NEVE DAS PALAVRAS
}

THE SNOW OF WORDS

\author{
Maria João Cantinho²
}

\section{RESUMO:}

Este artigo quer ler a vida de Paul Pessakh Antschel - nome verdadeiro de Celan. Paul Antschel muda o seu nome de Antschel para o anagrama Celan, que viria a conservar ao longo de toda a sua vida. As leituras de Marx e Nietszche, a par da poesia alemã, sobretudo Hölderlin e Rilke, mas também Goethe e Schiller, Heine, Trakl, Kafka, Hofmannsthal, entre outros, desenvolveram no poeta um gosto pela política e simultaneamente pela literatura. Música e morte entretecem-se, na poesia de Celan, evocando a atmosfera lírica de Schubert - A Morte e a Donzela - ou de Mahler, de Brahms e do Requiem Alemão, numa tentativa de harmonizar a mais dolorosa e insustentável vivência. Celebração, não da morte, mas daqueles que pereceram nos campos de morte, sob as condições mais desumanas que é possível imaginar-se e a dilaceração surge, de forma sublime, no poema "Fuga da Morte". No poema "A morte é uma flor", Celan alegoriza a morte através da imagem de uma flor, uma flor que "só abre uma vez". Trata-se de um mundo de uma beleza terrível, onde os mortos "brotam e florescem". Morrem para a vida, florescendo para a linguagem poética, a única capaz de resgatar a experiência do horror, pela via da rememoração. Rememorar a experiência vivida deve ser entendido como o gesto que simultaneamente leva a cabo a destruição dos elos orgânicos e, contrariamente, encerra em si uma pretensão redentora, essa a verdadeira finalidade da poesia de Celan.

Palavras-chave: Poesia; Celan; História; Linguagem; Rememorar.

\begin{abstract}
:
This article wants to read Paul Pessakh Antschel's life - Celan's real name. Paul Antschel changes his name from Antschel to the anagram Celan, which he would retain throughout his life. The readings of Marx and Nietszche, along with German poetry, especially Hölderlin and Rilke, but also Goethe and Schiller, Heine, Trakl, Kafka, Hofmannsthal, among others, developed in the poet a taste for politics and simultaneously for literature. Music and death are intertwined in Celan's poetry, evoking the lyrical atmosphere of Schubert - Death and the Maiden - or Mahler, Brahms and the German Requiem, in an attempt to harmonize the most painful and unsustainable experience. Celebration, not of death, but of those who perished in the death camps, under the most inhuman conditions imaginable, and the tearing comes, in a sublime way, in the poem "Death's Escape." In the poem "Death is a flower," Celan allegorizes death through the image of a flower, a flower that "opens only once." It is a world of terrible beauty, where the dead "sprout language, the only one capable of rescuing the experience of horror by way of remembrance. Recalling the lived experience must be understood as the gesture that simultaneously accomplishes the destruction of the organic links and, on the contrary, contains in itself a redemptive claim, that is the true purpose of Celan's poetry.
\end{abstract}

Keywords: Poetry; Celan; Story; Language; To remember.

1 Este artigo foi publicado pela primeira vez em 2005 pela Revista de estudios literarios. Universidad Complutense de Madrid. http:// www.ucm.es/info/especulo/numero30/aneve.html.

2 Maria João Cantinho é doutora em filosofia, jornalista e escritora, poeta. É membro integrado do Centro de Filosofia da Faculdade de Letras de Lisboa (desde 2012) e Membro Associado do Collège d'Études Juives et de Philosophie Contemporaine, Membro da Direcção do Pen Clube Português, da APE (Associação Portuguesa de Escritores) e da APCL (Associação Portuguesa de Críticos Literários). Publicou várias obras de Ficção, Poesia e Ensaio. É autora de : A Garça, editora Diferença, Leiria, 2001 ; Abrirás a Noite com um Sulco,editora Hugin, Lisboa, 2002 ; O Anjo Melancólico, editora Angelus Novus, Coimbra, 2003 ; Sílabas de Água, editora Ver-o-Verso, Porto, 2005. 
"O poema, sendo como é uma forma de aparição da linguagem, é por isso de essência dialógica, o poema pode ser uma garrafa lançada ao mar, abandonada à esperança - decerto muitas vezes ténue - de poder um dia ser recolhida numa qualquer praia, talvez na praia do coração. Também neste sentido os poemas são um caminho: encaminham-se para um destino (...) para um lugar aberto, para um tu intocável...".

- Paul Celan, 1958

"Só mãos verdadeiras escrevem poemas verdadeiros. Não vejo nenhuma diferença de princípio entre um aperto de mão e um poema".

- Paul Celan, 1958

O que mais nos impressiona, na abordagem da vida e obra de Paul Celan foi o modo trágico como o poeta assumiu a responsabilidade da sua época. Por isso, o fascínio de que se revestiu devese a essa dupla dimensão, entre o poeta que ele foi, no "limiar do emudecimento" e o ser humano, profundamente consciente da sua época e do seu tempo, tendo pago caro essa factura com os dissabores que isso lhe trouxe. Uma abordagem clara e rigorosa do homem, nas suas várias facetas, exige, por isso, a separação das "águas" entre a lenda em que ele se transformou e o homem (de uma fragilidade comovente) propriamente dito.

Edith Silbermann (2001), amiga de juventude de Paul Pessakh ${ }^{3}$ Antschel - nome verdadeiro de Celan -, refere esses aspectos que foram desvirtuados na sua biografia. Paul Antschel nasceu em 23 de Novembro de 1920, em Czernowicz, Bucovina (na Roménia). Filho único, Paul tem, desde cedo, o objectivo de ir para França estudar. E, de facto, parte em 1938, mantendo-se dois anos em Tours, a estudar medicina. É dessa data que nascem os primeiros poemas. Ela dá conta de um jovem ávido e iconoclasta, que defende corajosamente os seus ideais. As leituras de Marx e Nietszche, a par da poesia alemã, sobretudo Hölderlin e Rilke, mas também Goethe e Schiller, Heine, Trakl, Kafka, Hofmannsthal, entre outros, desenvolveram no poeta um gosto pela política e simultaneamente pela literatura. Para o grupo de jovens que acompanhavam Celan, a língua francesa "era a mais bela língua do mundo" (SILBERMANN, 2001, p.10). Liam Mallarmé, Valéry, Apollinaire, Baudelaire. Paul traduziu também sonetos de Shakespeare, poemas de Yeats, Apollinaire, entre muitos outros. Foi por este caminho que ele chegou à poesia.

Em 1940, começou a estudar russo e, nessa altura, começa a traduzir Sergeï Lessenine. A armada vermelha ocupa, entretanto, a sua cidade. Durante esse período, que vai de 1940 a 1941 (aquando das ofensivas de Hitler e recuo dos russos), os judeus não ousavam mostrar-se e revelar a sua religião, os seus costumes. Todavia, o irreverente Paul Antschel não se escondia e afrontava corajosamente esse medo. Como o relata Edith Silbermann, Paul adorava chamar a atenção sobre si próprio, o que the traria grandes desilusões.

É a partir de 1941 que os judeus são "empurrados" para o gueto, pelos alemães. Num dia em que ele sai miraculosamente de casa, antecipando o perigo e refugia-se, graças à sua amiga Ruth Lackner, numa fábrica de cosméticos, aguardando a chegada dos seus pais. Porém, a mãe de Paul 3 «Pessakh», o seu prenome, em hebreu significa «a boca que relata». 
negou-se, dizendo-lhe: "Não podemos escapar ao nosso destino". Nesse ano de 1942, os alemães prenderam os seus pais, que foram levados para um campo de concentração e, no espaço de alguns meses, ambos assassinados.

Pouco tempo depois, o próprio Celan alista-se num campo, em Tabaresti, na Roménia, onde se sente mais seguro do que na sua cidade. O trabalho duro que aí realizava deixava-lhe tempo, porém, para ler e escrever, para traduzir, vivenciando a miséria, o desastre e a destruição, à sua volta. Temas como "a morte na neve" serão um dos mais recorrentes da sua obra poética, testemunhando a tragédia dos judeus e, sobretudo, a dor da morte dos seus pais. O frio glacial, as pegadas e vestígios que se dissipam na neve são essas tantas formas metafóricas de exprimir a morte, metáforas que se apresentam de modo constante na sua poesia.

A derrota dos alemães, em 1943, estava, todavia, tão próxima que se permitiu aos residentes de Tabaresti o regresso às suas cidades e Paul regressou, então, a Czernowitz. Na Primavera, os soviéticos entravam, pela segunda vez, na sua cidade. Paul avistava um novo período menos cruel. Evitou, por essa altura, a entrada no exército russo, com alguma ajuda, pois a guerra ainda não havia terminado. Em compensação, trabalhou como ajudante numa clínica psiquiátrica, onde se encarregava de tratar os soldados soviéticos com feridas na cabeça e em estado de choque. Para ganhar dinheiro, realizava traduções para ucraniano, num periódico local. Reuniu, nessa época, um conjunto de 93 poemas dactilografados e entregou uma outra colecção escrita à mão à sua amiga Ruth Lackner, para que ela os fizesse chegar a Bucareste e os entregasse ao poeta Alfred MagulSperber. No Outono de 1944 retoma os seus estudos de inglês, na universidade que foi reaberta pelos soviéticos e entregou-se à leitura de escritores hebreus.

Após o término da guerra, alguns deportados voltaram dos campos e, entre eles, encontravase o seu amigo, o poeta Immanuel Weiglass ${ }^{4}$. Nessa época, Paul supunha que o seu tio, Bruno Schrager, tinha ficado em Paris, mas veio a constatar que o seu nome constava dos desaparecidos em Auschwitz, o que veio reacender o seu trauma. Começou, então, a escrever a primeira versão do poema "Fuga da Morte", o poema que o celebrizou e que tantos dissabores Ihe traria, numa polémica questão levantada por Theodor Adorno. Teve uma primeira publicação, em língua romena, no número de Maio de 1947, numa revista de Bucareste, Agora, graças à tradução do seu amigo Petre Solomon. Paul Antschel muda, então, o seu nome de Antschel para o anagrama Celan, que viria a conservar ao longo de toda a sua vida.

Felstiner dá conta do acontecimento terrível que parece estar relacionado com o poema, de forma mais directa. Num panfleto escrito por Konstantin Simonov, datado de 29 de Agosto de 1944, sobre o campo de extermínio de Lublin, o autor contava que durante os trabalhos no campo eram tocados tangos e fox-trots. Na revista romena, onde foi publicada a primeira tradução do poema, sob o título "Tango de Morte", um ano antes da publicação do original, uma nota de apresentação dizia que o poema publicado era construído a partir da evocação de um facto real. Um grupo de prisioneiros, nesse campo, era obrigado a cantar canções nostálgicas enquanto os outros abriam valas comuns. Mas existe, ainda, uma outra fonte de informação, a qual dizia que, num campo

4 Edith Silbermann, no seu artigo "Rencontre avec Paul Celan», in Europe, pp. 12, 13, refere que o poema "Fuga da Morte" se relaciona intimamente com as descrições que Weiglass fazia a Celan das condições de vida dos campos. 
próximo de Czernowitz (a cidade de Paul Celan), um comandante das SS obrigava violinistas judeus a tocar um tango, enquanto eram cavados túmulos e decorriam marchas, torturas e execuções. Um dia, o comandante disparou contra toda a orquestra.

Música e morte entretecem-se, na poesia de Celan, evocando a atmosfera lírica de Schubert - A Morte e a Donzela - ou de Mahler, de Brahms e do Requiem Alemão, numa tentativa de harmonizar a mais dolorosa e insustentável vivência. Celebração, não da morte, mas daqueles que pereceram nos campos de morte, sob as condições mais desumanas que é possível imaginar-se e a dilaceração surge, de forma sublime, no poema "Fuga da Morte":

Leite negro da madrugada bebemos-te de noite bebemos-te ao meio-dia e pela manhã bebemo-lo de noite bebemos e bebemos cavamos um túmulo nos ares aí não ficamos apertados $\mathrm{Na}$ casa vive um homem que brinca com serpentes escreve escreve ao anoitecer para a Alemanha os teus cabelos de oiro Margarete escreve e põe-se à porta da casa e as estrelas brilham assobia e vêm os seus cães assobia e saem os judeus manda abrir uma vala na terra ordena-nos agora toquem para começar a dança

O tema da "dança da morte", a atentar nas palavras de E. Silbermann (2001, p.13), já o havia preocupado antes. Celan conhecia bem os "Simulacros da Morte" de Hans Holbein e a tradição da dança macabra, nos poetas alemães e no imaginário medieval, onde a vida é de tal forma precária que o tema da "dança com a morte" assume uma visibilidade que o homem contemporâneo consideraria insuportável. Por outro lado, a questão prende-se igualmente ao problema da língua alemã. A língua em que Celan escrevia era a alemã, a mesma que os "mestres da morte" usavam. Essa terrível contradição - a de escrever numa língua que era a da sua mãe e também a dos seus carrascos ocupava-Ihe permanentemente o espírito e transformou-se numa das suas obsessões fundamentais e que se exprime da forma mais intensa na sua poesia, introduzindo nela uma profunda crispação:

\author{
(...)Mãe, eles escrevem poemas. \\ Oh, \\ mãe, quanto \\ chão do mais estranho dá o teu fruto! \\ Dá esse fruto e alimenta \\ os que matam! $(\ldots)^{5}$
}

Quando Derrida6, fala da experiência da morte em Celan, refere-se, também, ao aspecto da morte, tal como ela é vivida na experiência da língua: "Parece-me, a cada instante, que ele deve ter vivido esta morte. De muitas maneiras. Deve tê-la vivido por toda a parte onde sentiu que a língua alemã era morta duma certa maneira, por exemplo pelos sujeitos da língua alemã que fizeram um certo uso dela: ela é assassinada, morta (...) A experiência do nazismo é um crime contra a língua 5 O "fruto" aqui simbolizado é a língua alemã que, por sua vez, é a língua dos carcereiros. (CELAN, 1998, p. 33) 6 Entrevista concedida a Evelyne Grossman, a 29 de Junho de 2000, in Europe, p. 90. 
alemã. O que foi dito em alemão sob o nazismo, isso é uma morte. Há outra morte que é a simples banalização, a trivialização da língua alemã, não importa quando ou onde. $E$, depois, há uma outra morte que é aquela que não pode chegar à língua por causa daquilo que ela é, isto é: posta em letargia, mecanizada, etc. O acto poético constitui, então, uma espécie de ressurreição: o poeta é alguém que tem a tarefa permanente, numa língua que nasce e ressuscita, não de lhe dar um aspecto triunfante, mas despertando-a como se desperta um fantasma: ele desperta a língua e para tornar viva a experiência do despertar, do retorno à vida da língua [sublinhado meu], é necessário estar próximo do seu cadáver."

Esta experiência do limite da linguagem, de que tão bem falam Steiner (Langage et Silence) e Agamben ( $v$. Le Langage et la Mort), Blanchot (sobretudo no livro que é dedicado a Celan, Le Dernier à Parler) aproxima Celan da experiência poética de Hölderlin7, também ele no limiar do perigo. A visão corrosiva de Celan está próxima, igualmente, da visão benjaminiana do perigo que sofre, a cada instante, aquele que lida com a linguagem e a tarefa alegórica. Mais ainda, ela aproximase de Benjamin, no que se refere à tarefa da rememoração, tema por excelência do pensamento hebraico, tomado na sua mais ampla dimensão e que se articula com a da temporalidade do poema. Ambos comungaram da questão da cesura e do limite do dizer, com ele, igualmente, a tarefa da rememoração enquanto alvo da sua escrita. Ainda que esse alvo se colocasse, no caso de Celan, no cerne do paradoxo da insustentável experiência dos campos. Alegoria e rememoração são pólos constitutivos da poesia de Celan, no sentido em que a única experiência possível de rememoração e de luta contra o esquecimento só pode ser levada a cabo pelo gesto redentor da escrita. No caso de Celan, é na e pela linguagem poética que ela se opera.

Ainda a esse propósito, cito o notável estudo de António Guerreiro (2000), consagrado a Celan, "Paul Celan e o Testemunho Impossível". António Guerreiro fala na tarefa trágica da poesia, no autor, definindo-a como o "limiar do emudecimento" (GUERREIRO, 2000, p. 31). No texto Arte Poética, Meridiano e outros textos, Paul Celan cruza o seu pensamento com o de Heidegger e Lévinas, numa tentativa de (re)definição do "ser do poema", que nos remete para a dificuldade do poeta. "O poema mostra, e isso é indesmentível, uma forte tendência para o emudecimento." Nesse texto extraordinário, pela sua clareza, Celan dá conta da natureza da poesia. O poeta é dominado por esse pathos que é a experiência da linguagem, naquilo que nela confina - e com ela se entrelaça, obviamente - com a existência da realidade. António Guerreiro sublinha-o, dizendo: "E porque essa língua não está disponível desde logo, não existe senão através da experiência que leva o poeta ao encontro dela, ela é única." Celan recusa, aqui, a ideia de uma correspondência poema-realidade, o que nos conduziria, aos seus olhos, a uma visão mimética e empobrecida da realidade. O poeta é o que luta por ir, com os meios de que dispõe, ao encontro da realidade, através da linguagem. Assim, a ideia de um correlato entre a palavra poética e o real é algo que não existe como um dado previamente estabelecido. Este correlato pode existir ao nível da linguagem enquanto forma de comunicação (e isto não passa de uma hipótese), mas nunca ao nível do "dizer poético, onde persiste inevitavelmente uma irredutibilidade entre a palavra e o real. A concepção mimética (e aristotélica) da poesia e da linguagem é, assim, repudiada por Celan.

Por outro lado, a ideia de univocidade do poema caminha, par a par, com a afirmação anterior.

7 Nelly Sachs apelidou-o de Hölderlin contemporâneo. 
Tal é essa ideia da univocidade do poema, quando o poeta afirma: "O poema é solitário. É solitário e vai a caminho. Quem o escreve torna-se parte integrante dele." (CELAN, 1996, p. 57). Aquele que o escreve e o poema, embora sejam realidades díspares, na sua essência, confundem-se numa outra realidade, que é a do poema. Celan, não apenas recusa o mimetismo, como recusa igualmente o bilinguismo da língua8, reafirmando a sua univocidade.

Deste modo, tempo e poesia encontram a sua articulação no topos do poema e essa temporalidade é, na sua expressão mais vívida, a experiência da linguagem, no sentido em que o poeta "vai ao encontro da língua com a sua existência, ferido de realidade e em busca de realidade." (CELAN, 1996, p.34). Como quem lança uma mensagem numa garrafa, dirigindo-se essencialmente a um "tu apostrofável", o tempo do poema confunde-se com aquele que o escreve, como o afirma Celan (1996, p. 57), absorvendo-o, mas sustenta-se na frágil linha que se liga ao Outro, lugar onde o Eu se dissipa, libertando-se de si próprio.

Neste modo de pensar reconhecemos o próprio pensamento de Lèvinas, entendendo-se o poema, não apenas como o tempo da "respiração", como também o da direcção, o pôr-se a caminho do Outro, "falar em nome de um Outro, quem sabe se em nome de um radicalmente Outro."(p. 55). No vaivém do Eu para o Outro, o poema auto-sustenta-se na velocidade da respiração ou caminho, através da linguagem. Peter Szondi, amigo de Celan, compreendeu bem essa tripla e essencial função do poema, que ele tão bem analisou em vários dos seus poemas: "linguagem como figura, direcção e respiração."

Esta caminhada para o Outro corresponde a um reconhecimento do instante desse encontro e as ressonâncias que, aqui, se ouvem, além de Adorno, evocam, também, Schleiermacher, Lèvinas, Martin Buber e Rosenzweig ${ }^{10}$. E nesse instante do encontro não há a mínima certeza nem qualquer apoteose, mas o que João Barrento designa por uma "imperceptível mudança de respiração", o que atesta uma escuta do Outro e do mundo, dando-se num lugar que é já um impossível caminho, para parafrasear a expressão de Celan, onde as utopias se transformam em tal:"(...)encontro alguma coisa que me consola um pouco por, na vossa presença, ter percorrido este caminho do impossível, este impossível caminho.Encontro aquilo que une e como que conduz o poema ao encontro." (CELAN, 1996, p. 63).

"O impossível caminho de encontro ao outro" constitui-se como o paradoxo - e, enquanto tal, é condição alegórica da poesia - sobre o qual assenta toda a poesia de Celan. J. Barrento ${ }^{11}$ defende que a ancoragem da sua poética já não é o romantismo nem a ontologia de Heidegger, "em que a figura do «Autêntico» tem ainda um papel central." Quando, nesse contexto da relação com o Outro e na caminhada para ele, Celan fala do poema autêntico, ele afirma: "Só mãos verdadeiras escrevem

8 "Não acredito que haja bilinguismo na poesia. Falar com língua bífide - isso sim, existe, também em diversas artes ou artifícios da palavra e dos nossos dias, especialmente naqueles que, numa feliz concordância com o respectivo consumo cultural, sabem estabelecer-se, de forma tanto poliglota como policroma. Poesia - essa é a inelutável unicidade da língua." (CELAN, 1996, p. 69)

9 "Poesia: é qualquer coisa que pode significar uma mudança na respiração." (CELAN, 1996, p. 54).

10 Martin Buber e Rosenzweig constituem os sistemas mais aceites do pensamento judaico contemporâneo que Celan conheceu bem. Essa ligação à tradição judaica é cada vez mais profunda na sua obra, o que conduz a poética de Celan à dificuldade da interpretação, onde o pensamento judaico aparece cifrado e metaforizado.

11 Cf. Meridiano, posfácio, (CELAN, 1996, p. 80). 
poemas verdadeiros. Não vejo nenhuma diferença de princípio entre um aperto de mão e um poema." (CELAN, 1996, p. 66). O poema, de acordo com Celan, na sua obscuridade e complexidade, é autêntico. O ofício do poeta constitui-se, como o afirma Celan na Carta a Hans Bender, de acordo com a condição necessária da verdade e do caminho para o Outro. A relação que Celan, nessa carta, estabelece entre "ofício de mãos" e "construção do poema" revela, também, a íntima articulação entre a realidade e a poesia.

A construção do poema obedece à sequência dialógica do Eu com o Outro, do poeta com a Verdade. Porém, essa caminhada, do poema impossível que "fala em nome do outro" é, na sua contradição íntima, uma caminhada na direcção do abismo. Transforma-se no "poema absoluto" que não existe ou na "magestade do absurdo" (CELAN, 1996, p. 79). E este absurdo é a lei do poema, tal como o é da tragédia, na desmedida que é a paradoxal fonte de criação poética. Somos levados à conclusão de que a configuração do encontro com o Outro é necessária, na poética de Celan e, para tal, evoque-se aqui a forma do des-inter-esse de que João Barrento ${ }^{12}$ nos fala, de forma pertinente. Corresponde essa caminhada impossível a uma superação das poéticas do "hermetismo mais puro", assim como Lèvinas a efectua da fenomenologia e da ontologia. A sua poética não é da "simples ordem de compreensão com os meios da linguagem, é antes anterior a todas as formas de compreensão imediatamente humanas (do verdadeiro humano): o encontro com o Outro." (CELAN, 1996, p. 80). Procura uma outra linguagem, que se construa como a verdadeira língua, capaz de ultrapassar os limites da linguagem. Poderíamos aí perceber a busca de Celan por uma ideia da criação da "nova" palavra ou palavra poética, a partir de uma relação intensificada entre o hermetismo e a cabala. Todavia, se é possível falar da magia da palavra em Celan, esta magia, no dizer de Yvette Centeno (CELAN, 1993, p. XXI), é uma "magia de inversão"13, pois "a palavra não cria, a palavra reduz ou aniquila".

Como em Lèvinas (e também em Buber), a presença incontornável do Outro é o ponto arquimediano da sua poética que, embora não se Ihe dirigindo, o contém. Daí que exista e, sobretudo, preexista uma dimensão ética que lhe é inegável. Como Barrento o assinala, será possível colocar a poética de Celan sob a forma de uma "poesia das vítimas"? (CELAN, 1996, p. 81). Ou, para utilizar a expressão benjaminiana, como "salvação dos vencidos da história"? É justamente por isso que nos encontramos no limiar da mudez. "É impossível resistir ao apelo, à convocação imperativa do rosto do Outro, rosto sem rosto, porque, para Lèvinas, ele está para além das formas plásticas. Então, o poema enquanto acontecimento não é um acto da vontade que parte do sujeito, mas, antes, qualquer coisa a que o seu autor se submeteu, como que convocado por um chamamento. "O apelo do outro é irresistível, avassalador" (CELAN, 1996, p. 82), algo que se abate sobre o poeta que, assim, se vê absorvido pelo poema, tornando-se "parte integrante dele."

Esta é a dimensão ética ${ }^{14}$, na qual enraíza profundamente Celan, tomando Lèvinas como seu mestre de pensamento, ainda que não fale dele. Por isso, emergindo da fissura da linguagem, 12 "relação necessária na ordem do ente e de saída da ordem do Ser, da ontologia abstracta e neutra." (CELAN, 1996, p. 80)

13 Esta magia de inversão é tematizada por Adorno, em Teoria Estética, p. 354.

14 Numa passagem do Meridiano, Celan (1996) escreve: "Vivemos sob céus sombrios e...existem poucos seres humanos. Talvez por isso existam tão poucos poemas”. Esta passagem estabelece uma relação imediata entre a dimensão ética e a poesia, de que Celan tinha uma verdadeira consciência. 
o poema corresponde à abertura do caminho por entre os limites da linguagem, no limiar da experiência do emudecimento.

No magnífico prefácio que João Barrento faz à sua tradução de Sete Rosas mais Tarde, estabelece uma relação íntima e indissociável entre uma poética que - paradoxalmente - se alimenta dessa "relação constante com o Outro" e, em si mesma, tende para o emudecimento radical, que é da ordem de uma poética do inefável, a que preside uma simultânea sacralização e violentação ${ }^{15}$ da palavra poética. Esta dupla dimensão opera sobre a poesia de Celan uma tensão que se manifesta no modo como a antinomia a dilacera. Os poemas de Celan querem dizer o horror extremo e o desabar da esperança através do silêncio. Por isso, o seu conteúdo, como o nota A.Guerreiro ${ }^{16}$, citando Adorno, "torna-se negativo".

Esse niilismo cósmico de que Yvette Centeno ${ }^{17}$ dá conta, um niilismo que "anula o tempo e as suas fracturas", que faz cessar toda a capacidade de nomear e recuar a existência "para o abismo da essência não-diferenciada" parece converter-se na força motriz do poema, numa proximidade com a mística da negação de Jacob Böhme. Como a autora o afirma, "Não há salvação possível na obra de Celan, que não aponta caminhos, não filosofa, apenas lambe feridas que não cicatrizam mais." Não existe qualquer apaziguamento nessa poesia de um hermetismo que revela um mundo irreversivelmente contaminado, destruído. O hermetismo - e o cabalismo - da sua poesia reforça, através das suas imagens, esse esvaziamento do mundo e, ao mesmo tempo, permite a acentuação da intensidade dramática do real. Veja-se, por exemplo, no paradigmático poema "Cristal":

Não busques nos meus lábios a tua boca, Nem diante do portão o forasteiro, Nem no olho a lágrima.

Sete noites mais alto muda o vermelho para vermelho, sete corações mais fundo bate a mão à porta, sete rosas mais tarde rumoreja a fonte.

De uma forma admirável, Yvette Centeno analisa os elementos herméticos e cifrados, nesta poesia. Tudo, nesta combinação dos elementos sete, noite, rosa e coração, remete para a morte, alegorizando-a. E a morte que, aqui, é alegorizada é a de Israel, pois a rosa representa o estado de Israel. Podemos dizer que, embora exista uma alquimia entre a cabala e o hermetismo, porém, a palavra poética é, na sua poesia, uma aniquilação ou uma negação que apenas o silêncio liberta18.

Como o afirma, ainda, a autora, "Com Paul Celan habitamos o silêncio. O silêncio do tempo, o 15 Como o afirma Barrento, na p. XXXII, citando o texto Meridiano, "A esta utopia da linguagem, que num mesmo lance sacraliza e violenta a palavra poética, chamará Celan o "poema absoluto», o poema que não existe nem pode existir, o lugar onde todos os tropos e metáforas são levados ad absurdum"

16 Op. Cit., p. 47, 48.

17 Prefácio à tradução de Sete Rosas mais Tarde, ed. Cotovia, p.XIX.

18 A ideia de um silêncio como "elemento místico fundamental de toda a revelação possível" parece constituir-se como uma ideia subjacente à poética de Celan. Esta concepção não é nova e conhece o seu pleno desenvolvimento na mística da Antiguidade tardia, com os gnósticos e o cristianismo. Ver, a este propósito, a obra de Agamben, Le Langage et la Mort, pp. 115/117. Podemos encontrar o desenvolvimento deste tema na 
silêncio do espaço entre as palavras" (CELAN 1993, p.XIX). Mas este silêncio não se situa no coração da plenitude e sim no domínio do exílio, do fragmento, da impotência. É um mundo de desespero e ausência de amor, da redenção, que aí ressuma. Mesmo quando uma fímbria de luz persiste debilmente, ela não faz senão acentuar o negrume e o caos do seu universo. Uma irreversível fractura ${ }^{19}$ persiste, contaminando tudo. E a poesia de Celan é o lamento ou o requiem por esse mundo que se sabe irremediavelmente destruído. O que nos sobra são as testemunhas impassíveis e silenciosas, que se exprimem nas metáforas recorrentes: as árvores, a neve, onde se dissipam as pegadas dos que nela pereceram, um olho (o olho do tempo) cego e que nada vê nem reflecte nada, o cabelo que sobrou, as cinzas. Na sua demanda de silêncio, a palavra poética sofre a erosão e a degradação, desarticula-se, torna-se inerte e o sentido morre, dando lugar ao absurdo. Perde, assim, a sua organicidade, numa implosão da linguagem que a desintegra. O desespero fala mais alto e não existe para o homem, neste mundo, qualquer redenção possível nem nenhuma lei salvadora20. Ainda que Celan tenha consciência de que o regresso à teologia hebraica poderia fornecer-lhe a âncora salvadora e, assim, poderia proteger-se e acolher-se no abrigo dessas categorias, ele não crê e afasta-se voluntariamente, atestando o mais virulento pessimismo e exprimindo a vertigem niilista.

0 Rosto do Poema: ares de família e responsabilidade da poesia face ao Outro

Tal como em Lèvinas, também o rosto e o poema - no caso de Lèvinas é o discurso filosófico - estão ligados entre si. É na representação simbólica do rosto que se "diz" o poema. O rosto não é "visto", o rosto fala. "O sentido é o rosto de Outrem e todo o recurso à palavra se coloca no frente a frente original da linguagem" (LÉVINAS, 1988, p. 185). É este confronto com o Outro que fundamenta a linguagem e que the confere a significação. Por isso, o discurso (no seu caso, a poesia) não pode deixar de ser dialógico, postulando o encontro o "lugar" da linguagem poética. Nesta medida, Celan rejeita a postura hermética e também o formalismo. "Discurso é «resposta» e «responsabilidade», e esta é para o filósofo e o poeta, o fundamento da «relação autêntica»"(CELAN 1996, p. 83). Esta comunidade entre Lèvinas e Celan ${ }^{21}$, a de um discurso da «relação» ou - no caso de Celan - de uma poética da «relação», revela-se de forma admirável no verso "Sou tu quando sou eu".

Como A. Guerreiro afirma, "a situação da poesia de Paul Celan é a de pós-catástrofe, palavra de sobrevivente que luta contra a ameaça do emudecimento" (GUERREIRO, 2000, p. 36), transportando consigo a experiência da dor, entendida como experiência do choque (Erlebnis). Não por acaso Celan vê em Ossip Mandelstam (poeta vencido pela história, morto nos campos gelados da Sibéria) uma profunda coincidência com a sua poética. Por essa mesma razão, ele saiu profundamente ferido pela afirmação de Adorno. Numa carta que Celan escreve a familiares, residentes em Israel, datada obra de Steiner, A Torre de Babel, ed. Relógio d’Água, Lisboa, 2004, no capítulo consagrado ao gnosticismo.

19 E que é também a fractura da linguagem, exprimindo essa irreconciliação.

20 E aqui podemos remeter o leitor para a questão do absurdo da lei em Kafka, também ele tentado pela teologia hebraica, mas, ao mesmo tempo, reconhecendo a impossibilidade da salvação humana, neste mundo, dominado pelo absurdo das leis e convenções.

21 Refira-se a presença do pensamento de Martin Buber, também, no modo como Celan o incorpora na sua poética. 
de 1948 e citada por John Felstiner, Celan afirma: "Não há nada no mundo que possa levar um poeta a deixar de escrever, nem mesmo o facto de ser judeu e o alemão a língua dos seus poemas."

A coragem do poeta reside, precisamente, no modo como assume em si a configuração desse paradoxo: se, por um lado, ele vai à procura do Outro e caminha para ele, nada recusando (tal como o herói trágico se sabe impedido de recusar o destino); por outro, tem de lutar contra os limites que Ihe são impostos pela linguagem. Não se conforma com a mudez que pesa sobre a História como uma maldição, mas "morde o destino" e a dor de dizer o insustentável. Ele é tomado por um imperativo ético de dizer o "indizível" e é nessa medida que o lirismo (falo de lirismo no sentido em que Philippe Lacoue-Labarth o tomou) de Celan atinge os seus contornos mais pungentes.

A Noite das Palavras

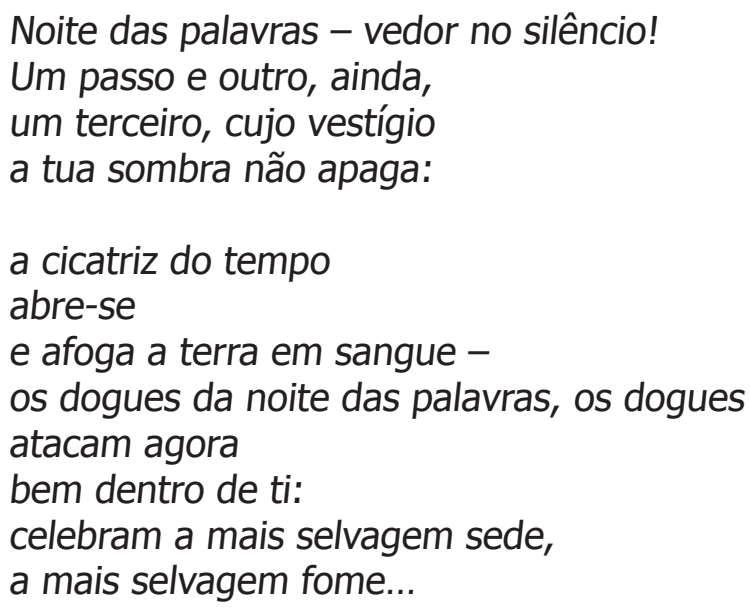

Paul Celan, "Noite das Palavras", in De Limiar em Limiar.

Rejeitando a "mística" de Auschwitz e defendendo Celan, Giorgio Agamben recusa a "indizibilidade" que Ihe é conferida por Adorno. Agamben (1998) reconheceu, contra a brutalidade da afirmação de Adorno22, a poesia de Celan como a mais "poderosa refutação" das teses contra a indizibilidade do extermínio. Mesmo quando ela se configura de forma pungente no poema "Uma canção do Deserto": "Pois mortos estão os anjos e cego ficou o Senhor na região de Acra".

Curiosamente, Peter Szondi, amigo de Paul Celan, revelou² que Adorno projectava, até ao final da sua vida, escrever um ensaio sobre Celan, o que permite deduzir que Adorno retrocedeu no seu veredicto sobre a poesia e acreditava, mesmo, que Celan derrubava o seu enunciado. Via-se, assim, obrigado a reformulá-lo, dizendo que "os autênticos artistas do presente são aqueles em cujas obras se repercute o extremo horror" (GUERREIRO, 2000, p.44). Contornando a questão e abrindo a possibilidade de uma estética da pós-catástrofe, Adorno parece, não ter negado, mas antes superado o que dissera antes, levantando o interdito que lançara sobre a arte e a poesia. Adorno

22 É preciso que se entenda bem a posição de Adorno, que rejeita o facto de que o horror se transfigure em princípio de prazer estético.

23 Cf.: (GUERREIRO, 2000, p.44) 
compreendeu, então, claramente que o sofrimento não suporta o esquecimento. Ainda que esse ensaio não tivesse existido, Adorno consagrou uma parte da sua Teoria Estética ao que ele considera "o mais significativo representante do hermetismo da lírica contemporânea" (GUERREIRO, 2000, p.44) (tema que, desde o início da recepção crítica de Celan, sempre esteve presente). Porém, Adorno retoma o tema do hermetismo em Celan, de forma diversa e, como o afirma este autor (ADORNO, s/d, p 44), a "opacidade" da poesia de Celan adquire uma transparência que tem a sua génese na vergonha da dor e na impossibilidade de dizer o horror. O silêncio dos poemas de Celan, na sua óptica, atinge o seu paroxismo precisamente porque eles querem dizer o horror extremo e que se aproxima, também, do "afundamento da aura" de que Benjamin dá conta na experiência baudelaireana, ao referir a distinção entre Erfahrung (experiência autêntica) e Erlebnis (experiência vivida do choque). A abissal diferença entre a autenticidade do Aqui e Agora do acontecimento dissipa-se sob o efeito da repetição do tempo e da mecanicização. Tal como em Baudelaire, o lirismo de Celan é um lirismo sem aura e que desconhece as correspondências do lirismo romântico.

Se a primeira versão do poema "Fuga da Morte", que apareceu no primeiro livro (A Areia das Urnas), ainda trazia em si o selo de uma transfiguração lírica, no entanto, Celan tentará, posteriormente travar a sua circulação. A declaração, feita por ele, numa entrevista, em Bremen, por altura da cerimónia da entrega do prémio, dá a compreender a sua reserva: "No meu primeiro livro (...)estava ainda a transfigurar as coisas - algo que não voltarei a fazer." (GUERREIRO, 2000, p. 51).

No ano seguinte, em 1949, era publicado o livro Grelha de Linguagem, que terminava com o poema "Stretto", que, de acordo com Szondi, era o exemplo mais acabado da via para a qual Celan se tinha, desde sempre, orientado. Considerado, por muitos estudiosos, como uma nova versão de "Fuga da Morte", não existe nele qualquer concessão à mimesis, nenhuma concessão ao que se entendia, anteriormente, por transfiguração lírica da realidade. A atentar nas palavras de Szondi, a este respeito, "a poesia deixa de ser mimesis, representação: ela torna-se realidade" (GUERREIRO, 2000, p. 51). A ideia de "paisagem-texto", como o refere Szondi, "para onde o leitor é transposto sem possibilidade de sair porque deixou de haver um fora e um dentro, um antes e um depois, é da maior importância para avaliar o alcance deste poema de Celan". A realidade configura-se como algo a ser conquistado 24 e "o lugar a partir do qual o poeta se orienta e projecta a realidade é a própria linguagem". A análise acutilante de A. Guerreiro dá-nos a compreender que estamos diante de uma reinversão do suposto aristotélico da mimese e que coloca questões fundamentais com as quais se debate a literatura contemporânea. O poema, para Celan, "não transfigura, não poetiza". É necessário, para entrar neste universo, onde as palavras mordem o insustentável horror sem o embelezar, fazer um exercício de abstracção sobre a poética de Celan, fechada sobre si. Szondi, não apenas um crítico admirável, mas profundo conhecedor da poesia de Celan e seu amigo próximo, refere um fechamento no "universo hermético do simbolismo", que se vai acentuando a par desse percurso para um silêncio cada vez mais obstinado e irreversível.

Estudos realizados como os de Szondi, em particular, vieram iluminar a poesia de Celan, mostrando que, apesar do seu contexto histórico e político - circunscrevendo-se à sua época -

24 "O poema(...) vai ao encontro da língua com a sua existência, ferido de realidade e em busca de realidade." (CELAN, 1996, p. 34) 
não deixa de lado uma dimensão fundamental e reflexiva, que suscita contornos interessantes e questões pertinentes no quadro das poéticas contemporâneas.

O facto de Celan ter traduzido poetas importantes e marcantes, na sua época, parece ter-se convertido num ponto a favor para a prática reflexiva e estética. Saliente-se o texto O Meridiano como aquele que mostra, na sua essência, o que pensa Celan acerca da poesia e da arte em geral. Trata-se de uma experiência de confronto consigo própria. É precisamente nesse estatuto que ela obriga a "uma revisão de todas as aporias e interditos" (GUERREIRO, 2000, p. 57). Salientese, como já foi referido, a experiência da poesia como um "compromisso com a verdade", tão irrefutavelmente expressa na sua afirmação de que "poemas verdadeiros se escrevem com mãos verdadeiras". E, desse ponto de vista, parece-me ser fundamental a compreensão da poesia de Celan, na sua autenticidade: enquanto tarefa de luta contra o esquecimento, como rememoração ou salvação dos "vencidos da história".

Como outros sobreviventes do Holocausto, a questão da rememoração coloca-se como o eixo fundamental da obra. E, nesse sentido, mais do que matéria de reflexão estética, a poesia de Celan coloca-se no centro das questões éticas do século XX. Trata-se de questionar a impossibilidade de esquecimento do mal, na sua banalidade, para parafrasear Hanna Arendt, tal como ele ocorreu, nos seus contornos mais insustentáveis. Uma tarefa que se constitui como um baluarte contra o silêncio da história. Confinando, na sua radicalidade, com a loucura e o emudecimento. Tome-se o poema "Argumentum e Silentio":

Acorrentada

entre o ouro e o esquecimento:

a noite.

Ambos a desejaram.

$A$ ambos se ofereceu.

Põe

põe tu também ali o que

amanhecerá com os dias:

a palavra sobrevoada de estrelas,

submersa pelo mar.

A cada qual a sua palavra.

A cada qual a palavra que cantou para ele, quando a matilha o atacou pelas costas -

A cada qual a palavra que cantou para ele, petrificando.

A ela, a noite, sobrevoada de estrelas, submersa pelo mar, a ela, ganha pelo silêncio, a quem não gelou o sangue quando o dente venenoso atravessou as sílabas.

A ela a palavra ganha pelo silêncio.

Contra as outras que breve prostituídas pelos ouvidos dos verdugos também escalarão o tempo e os tempos dá por fim testemunho (...) 
O estilhaçamento da palavra nasce desse confronto persistente com o silêncio que confina com ela. Como o afirma A. Guerreiro, a poesia de Celan, não apenas confina com o emudecimento, no seu limite, como igualmente se confronta com a ausência de ilusão e de esperança. Nesse sentido, ela "é remetida para a pura imanência das palavras sem garantia, isto é, para a própria matéria da língua" que fez a travessia dos acontecimentos e que renasceu disso. 0 facto de confinar com o silêncio, numa poética do inefável, faz com que muitos estudiosos aproximassem Celan de Hölderlin, esse poeta extraordinário e paradigmático, que atravessou a noite da loucura com a frágil luz das palavras. Porém, Celan rejeitava o formalismo de Hölderlin, em que o queriam encerrar. Afirmava a Solomon a convicção de que todos os poemas haviam sido escritos numa relação directa com a realidade, de acordo com as palavras de Felstiner.

Todavia, se os seus poemas se suportam nesta relação directa com a realidade, não é possível lê-los ${ }^{25}$ como se lê, em geral, a literatura que testemunha, de acordo com o modelo da chamada "literatura dos campos". Há uma componente de subjectividade que é anulada, atenuada e não é possível reconhecer-se um lirismo confessional, de que Celan se afasta com veemência. Esse mesmo lirismo que Adorno condena no seu veredicto, daí que a interdição tenha ferido sobremaneira Celan.

A poesia não se limita à descrição dos factos e a testemunhá-los, ainda que haja (como o defende Celan) uma relação directa com os acontecimentos. Ela opera sobre a matéria um efeito criativo, que faz nascer uma outra realidade. Uma autonomia subsiste no coração desta transformação, que permite os elementos conheçam uma nova ordem, uma ordem de pertença, num outro contexto, na linguagem. Esse modo de operar exige uma reinversão da própria linguagem, uma "ruptura" com a linguagem, "que tem de ser vista na sua relação com o abismo, aberto pelos acontecimentos da história", como o refere A. Guerreiro (2000, p. 65). Daí que esta reinversão se faça na direcção do hermetismo, como salienta, a este propósito, Adorno: "No representante mais importante da poesia hermética da lírica alemã contemporânea, Paul Celan, o conteúdo experimental do hermetismo inverteu-se. Os poemas de Celan querem exprimir o horror extremo através do silêncio. $O$ seu próprio conteúdo torna-se negativo. Imitam uma linguagem aquém da linguagem impotente dos homens, e até de toda a linguagem orgânica, a linguagem do que está morto nas pedras e nas estrelas." (ADORNO, s/d, p. 354). Esta linguagem que privilegia o inanimado e que caminha do horror ao silêncio, Adorno reconhece uma transformação a que chama a "transição para o anorgânico". Como já o referimos, o processo está próximo daquele que Benjamin identifica em Baudelaire, reconhecendo o "afundamento da aura" e das correspondências entre os seres. Tudo aparece, assim, morto e destituído de sentido, nesta linguagem, que se configura como um balbuciar emergente ${ }^{26}$, numa nova ordem da realidade linguística.

Esse radicalismo de Celan é, sem dúvida, a principal característica da sua poesia, levado ao seu extremo, na perda total do último reduto do homem: a sua humanidade, no confronto com a ausência de Deus. Leia-se o poema "Salmo", em A Rosa de Ninguém(CLEAN, 1998, p. 103):

25 Veja-se, a este propósito, as notáveis considerações de A. Guerreiro sobre a "ilegibilidade" da poesia de Celan, em que se tecem comparações com o pensamento da "legibilidade", no pensamento hassídico de Martin Buber e a poesia de Hölderlin.

26 É nesta medida que se coloca, também, o problema da "ilegibilidade" da poesia de Celan, onde a morte da aura e das correspondências entre os seres e a sua organicidade dá lugar ao estilhaçamento e à fragmentação da linguagem, colocando como prementes a questão da afasia e do emudecimento.

21

revista albuquerque, vol. 11, n.21, jan-jun de 2019 
Ninguém nos moldará de novo em terra e barro, ninguém animará pela palavra o nosso pó.

Ninguém.

Louvado sejas, Ninguém.

Por amor de ti queremos

Florir.

Em direcção a ti.

Um Nada

fomos, somos, continuaremos

a ser, florescendo:

a rosa do Nada, a

de Ninguém(...)

O caminho de Paul Celan é de uma radicalidade assombrosa, se compararmos o seu percurso a outros poetas como Ossip Mandelstam ou René Char, a Henri Michaux, Yves Bonnefoy ou, ainda, tantos outros poetas contemporâneos, que viveram igualmente a tragédia dos campos de extermínio. E este trilho amaldiçoado pela mudez aparece cada vez mais pejado de escombros e ruínas, num crescendo que atinge o desespero dos seus últimos poemas. Talvez nenhum poeta tenha encarnado a tragédia da linguagem como Celan, nem mesmo Hölderlin (apesar da loucura, a luminosidade persiste na sua poesia). A vida de Celan mediu-se pela areia da linguagem, que lhe escorria entre os dedos, intangível realidade ou devastada paisagem, para sempre perdida. A sua recusa do lirismo (que Adorno não terá compreendido, inicialmente) está relacionada com a recusa da ilusão, com o imperativo ético de fincar a poesia na realidade.

Ironicamente, para aquele que recusava o lirismo, a sua única forma de habitar a linguagem radicava na experiência poética e, por isso mesmo, recusava a narrativa e a ficção, que considerava como uma espécie de degradação da linguagem. Aqui, a contradição atinge o seu clímax. A poesia é o espelho cego de uma experiência insustentável, mas que se deseja na sua pureza, na transparência e na dizibilidade possível da linguagem. Ela, poesia, é vivida como "experiência-limite", à qual Celan sucumbirá. Leia-se o seu último poema:

\author{
Vinhateiros escavam \\ o relógio das horas sombrias \\ cada vez mais fundo, \\ tu lês, \\ o Invisível \\ desafia \\ $o$ vento, \\ tu lês,
}

os Abertos trazem 
a pedra atrás do olho,

ela te reconhecerá,

no dia do Sabbath.

\author{
A Rememoração Possível \\ Este é o olho do tempo: \\ Olha de través \\ sob um sobrolho de sete cores. \\ A sua pálpebra é lavada com fogo, \\ a sua lágrima é vapor. \\ A estrela cega voa para ele \\ e derrete na pestana mais ardente: \\ o mundo aquece \\ e os mortos \\ brotam e florescem.
}

Paul Celan, "Olho do Tempo"

Poderemos definir a poesia de Celan como um cântico de redenção? Se existe, na sua poesia, uma réstea de luz, ela exprime-se nesse desejo, profundamente alegórico, de tentar "restaurar" o sentido, numa ordem diversa do plano dos factos vivenciais e insustentáveis do extermínio. Redenção, também, da língua, essa língua que é a da sua mãe e, simultaneamente, dos "mestres da morte". Redenção como rememoração, naquele sentido em que se toma a rememoração, não como memória, mas (re)construção da memória, no sentido em que Benjamin o toma, na análise sobre o texto proustiano e a alegoria de Baudelaire: "a rememoração representa esse gesto(...)do poeta que leva a cabo a cabo a alegoria, como bem o nota Walter Benjamin, distinguindo claramente rememoração de memória quanto às funções respectivas de cada uma, seguindo as pisadas da teoria psicanalítica e, em especial, de Theodor Reik: a memória (...)«tem por função proteger as impressões, a rememoração visa desintegrá-las. A memória é essencialmente conservadora, a rememoração é destrutiva»"(CANTINHO, 2002, p. 105). O tema da rememoração é essencialmente uma das questões judaicas mais profundas e pertinentes. Lembro apenas, entre muitos outros, os notáveis estudos de Michael Löwy, Gershom Scholem²7.

Se tomarmos como ponto de partida as investigações freudianas e, sobretudo, o tema do recalcamento, é possível estabelecer claramente a distinção entre o que é da ordem da memória (a memória inconsciente) e a estrutura que assenta na base do procedimento alegórico e que, no seu essencial, o explica: a rememoração [Eingedenken]. Rememorar a experiência vivida deve ser entendido como o gesto que simultaneamente leva a cabo a destruição dos elos orgânicos e, contrariamente, encerra em si uma pretensão redentora, essa a verdadeira finalidade da poesia de Celan. Daí, tornam-se claras as palavras de J. Barrento quando fala, no que se refere à sua poesia,

27 Tema que tem por fundamento uma raíz teológica tradicional, no pensamento judaico. Veja-se as obras de Michael Löwy, L’Avertissement de l'Incendie, Revolução e Utopia. 
de uma concomitante sacralização e violentação da palavra poética. Este gesto é, por excelência, correspondente ao olhar alegórico, que nasce do (re)conhecimento dessa violência dilaceradora que habita o cerne das coisas, da visão terrível do dente da morte roendo o vivo. No poema "A morte é uma flor", Celan alegoriza a morte através da imagem de uma flor, uma flor que "só abre uma vez". Trata-se de um mundo de uma beleza terrível, onde os mortos "brotam e florescem". Morrem para a vida, florescendo para a linguagem poética, a única capaz de resgatar a experiência do horror, pela via da rememoração.

Um arrepio de assombro percorre-nos diante dessa imagem de irreversibilidade e impotência alegórica. O contraste do belíssimo verso "E vem, grande mariposa, adornando caules ondulantes" com a iminência da morte confere-Ihe um tom profundamente pungente e dilacerador. É nesta violência lírica da palavra que cintila o esplendor da poesia de Celan, mesmo se turvada pelo negro sol da melancolia.

\section{REFERÊNCIAS}

ADORNO, Theodor. Notes sur la Littérature. Paris: Flammarion, 1984.

ADORNO, Theodor. Teoria Estética. Lisboa: Edições 70, s/d.

AGAMBEN, Giorgio. Quel che resta di Auschwitz. Turim: Bollati Boringhieri, 1998.

BLANCHOT, Maurice. Le Dernier à Parler. Montpellier, Fata Morgana.

CANTINHO, Maria João. O Anjo Melancólico. Coimbra: Ed Angelus Novus, 2002.

CELAN, Paul. A Morte é uma Flor, tradução de João Barrento Lisboa: Edições Cotovia, 1998.

CELAN, Paul, Arte Poética. O Meridiano e Outros Textos. Tradução de João Barrento. Lisboa: Edições Cotovia, 1996.

CELAN, Paul. Sete Rosas mais Tarde, tradução de Yvette Centeno e João Barrento. Lisboa: Edições Cotovia, 1993.

DERRIDA, Jacques. Schibboleth pour Paul Celan . Paris: Galilée, 1986.

FELSTINER, John, Paul Celan. Poet, Survivor, Jew. Yale: Yale University Press, N.Y., 1995. 
GUERREIRO, António. O Acento Agudo do Presente. Lisboa: Edições Cotovia, 2000.

LACOUE-LABARTHE, Phillippe. La poésie comme Expérience. Paris: Christian Bourgois, 1986.

LÉVINAS, E.Totalidade e Infinito. Lisboa: Ed.70,1988.

SILBERMANN, Edith. «Rencontre avec Paul Celan», in Revue Europe, no 861-862, Janvier, Fevrier, Paris, 2001.

RECEBIDO EM: $10 / 05 / 2019$

APROVADO EM: 30/06//2019 